\title{
The Competition and Equilibrium Condition among the China Banks
}

\author{
Xinyue Chu, Sitong Chen \\ Queen Mary University of London, London, England \\ Email: 1372922201@qq.com
}

How to cite this paper: Chu, X. Y., \& Chen, S. T. (2021). The Competition and Equilibrium Condition among the China Banks. Open Journal of Business and Management, 9, 2479-2486.

https://doi.org/10.4236/ojbm.2021.95134

Received: August 25, 2021

Accepted: September 20, 2021

Published: September 23, 2021

Copyright (c) 2021 by author(s) and Scientific Research Publishing Inc. This work is licensed under the Creative Commons Attribution International License (CC BY 4.0).

http://creativecommons.org/licenses/by/4.0/

\begin{abstract}
Since the beginning of the financial crisis, no matter the domestic or the international environment of the bank industry has become more complex and the competition also becomes fiercer. After a series of financial system reforms, China's banking industry has already actively participated in the fierce market competition. This paper examines the competitiveness and equilibrium of China's commercial Banks from 2008 to 2017 by using the Panzar-Rosse model. At the end of this essay, some suggestions are proposed, so as to ensure that in the furious market competitiveness, the banking industry of China can develop healthily and placidly.
\end{abstract}

\section{Keywords}

Competition, Equilibrium, PR Model

\section{Introduction}

Before the 2008 subprime crisis, the public believed that no financial crisis would greatly affect large banks, not to mention it will go bust. However, in 2008, Lehman Brothers Holding Inc., America's fourth largest investment bank failed to invest, triggering a global financial tsunami. Confidence in the market has undermined, and about 400 banks failed during the subprime crisis period. However, there are several Banks not only survived but also have been developed due to their strong risk tolerance. For example, Citibank of the United States, in 2008, its tier 1 capital was 118.8 billion dollars, ranking third in the world, and its tier 1 capital adequacy ratio was $11.9 \%$. Moreover, while it lost $\$ 53.1$ billion that year, it raised $\$ 104.3$ billion in capital, far more than it lost. Citibank also bought the operations of Wachovia, the fourth-largest U.S. bank, that year.

The banking sector of China has also been extremely affected. The market share of state-owned Banks in deposit, loan and other aspects has been reduced. 
Joint-stock Banks, on the contrary, have been developed and expanded, and participated in the market competition actively. The change in proportion is evident from Figure 1. The competitive situation of China's banking industry presents new characteristics, and how to maintain the balanced development of the banking industry under such circumstances is the main research content of this paper.

In the theoretical research of competition measurement, there are two main research frameworks: structural and unstructured. The Panzar-Rosse model which is derived from unstructured frameworks is selected in this paper. The data results from Macrobond and bankscope. Empirical research shows that commercial Banks of China stays in a long-term equilibrium, which means it can develop smoothly and healthily in the fierce competition.

\section{Literature Review}

The impact of bank competition on financial fragility has always been a prevalent topic in the academic community and the policymaker. Because of this a relatively complete system has been formed from the initial theoretical exploration stage to the present empirical methodology. Panzar-Rosse model is the main theoretical support of this paper.

The Panzar-Rosse model (PR model) was proposed by Panzar and Rosse (1987) based on the Byrd model with summarized, and a $H$ value was used to measure competition conditions. Since the PR model was proposed, it has been attached great importance by scholars. PR model is mainly analyzed from two perspectives: transnational perspective and single country perspective. There is a large number of scholars choose to across transnational perspective to verify their research. Molyneux et al. (1994) studied the banking markets of France, Germany, Britain, and Spain from 1986 to 1989, and found that except for the German banking industry in 1987, the banking industry of four countries all behave like monopolistic competition. Moreover, their research also proves that most regression data can be tested by the equilibrium test, so the interpretation

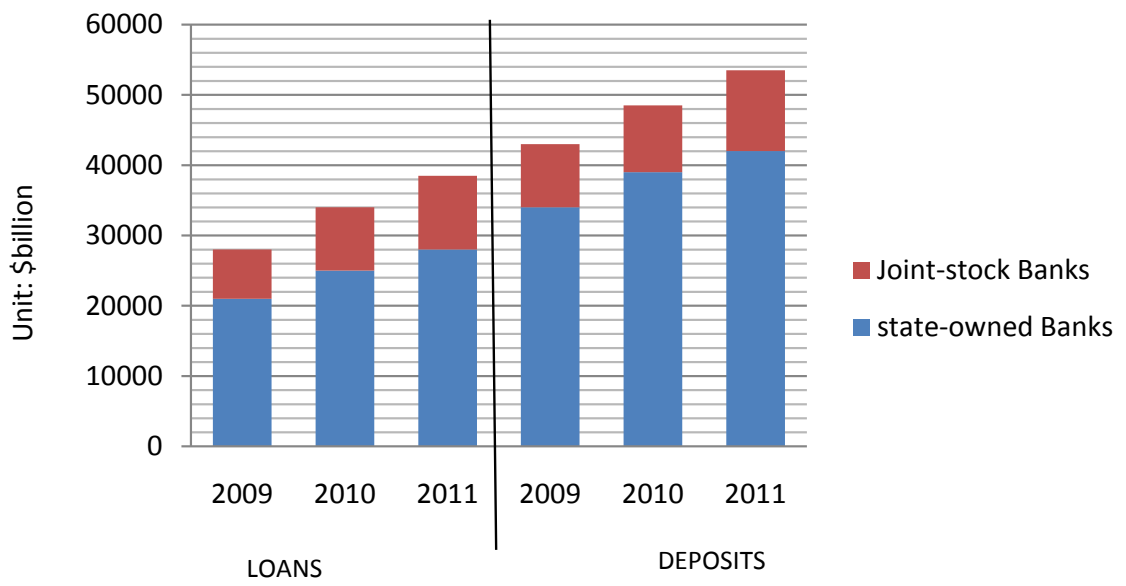

Figure 1. Balance of deposits and loans of state-owned and joint-stock banks from 2009 to 2011 . 
of $H$ statistic is meaningful. On the other side, the single country perspective of PR model is also popular in academic circles. Hempell (2002) using the PR model to study the German banking system from 1993 to 1998. Banks were classified by size and found that the bigger the bank is, the bigger the $H$ value is, and vice versa. Bikker and Haff (2002) across using the PR model to research banking industry in 23 industrialized countries; they compared the value of $\mathrm{H}$ and concluded that Banks in 23 countries are all monopolistic competition. Gunji and Yuan (2017) indicate that this model is available in an increasing-returns-to-scale technology as well.

At present, the research on PR model is mainly concentrated in developed countries. This paper takes China as an example to study the state of monopoly and equilibrium in developed countries, so as to provide theoretical and empirical support for PR model.

\section{Theoretical Framework-Methodology}

This article tries to calculate the competition degree of Chinese commercial Banks through the PR model. This model uses the cross-period data to establish the simplified income equation and analyzes the degree of industry competition according to the different price elasticity changes between income and input factors. In this model, the sum of all input factors and the price elasticity of income in PR model were named as $H$ value, and it is mainly used to indicate the degree of market competition.

$$
H=\sum_{k=1}^{m} \frac{\partial R_{i}^{*} w_{k i}}{\partial W_{k i} R_{i}^{*}}
$$

Molyneux et al. (1994) gave a detailed explanation of the different values of $H$. See details from Table 1.

Through comparison of relevant literature, this paper builds an empirical model by referring to Bikker and Haff's (2002) regression equation, which can help test the competition degree of Chinese banking market.

$$
\begin{aligned}
\ln \mathrm{REV}_{i t}= & \alpha_{0}+\alpha_{1} \ln \mathrm{PL}_{i t}+\alpha_{2} \ln \mathrm{PK}_{i t}+\alpha_{3} \ln \mathrm{PF}_{i t} \\
& +\beta_{1} \ln \text { Rissass }_{i t}+\beta_{2} \ln \text { Asset }_{i t}+\mu_{i}+v_{i t}
\end{aligned}
$$

Table 1. Meaning of $H$-value.

\begin{tabular}{cc}
\hline$H$-VALUE & TYPE OF THE MARKET \\
\hline$H \leq 0$ & Monopolized or Oligopoly Monopolized \\
$0<H<1$ & Monopolistic competition \\
$H=1$ & Complete competition or a natural monopoly \\
\hline
\end{tabular}

\footnotetext{
${ }^{1} R_{i}$ represents the marginal revenue of bank $i, C_{i}$ represents the marginal cost of bank $i, x_{i}$ represents the output of bank $i, n$ represents the number of Banks, $w_{i}$ represents the price vector of a survival factor input of bank $i, z_{i}$ is the exogenous variable of bank earnings function, and $t_{i}$ is the exogenous variable of bank cost function. Secondly, equilibrium should be realized at the market level, that is, the constraint conditions of zero profit should be satisfied. $R_{i}^{*}\left(x^{*}, n^{*}, z\right)-C_{i}^{*}\left(x^{*}, w, t\right)=0$. *represent the equilibrium constant of each variable.
} 
Shaffer (1982) put forward that if the market is not in long-term equilibrium, it will lead to a negative distortion of $H$ statistics. Under the condition of market equilibrium, $H$ value, which is the ROA to the sum of the price elasticity of change of each input factor is equal to 0 . If the $H$ value is not equal to 0 , the market does not satisfy equilibrium conditions. The market equilibrium test model is:

$$
\begin{aligned}
\ln \mathrm{ROA}_{i t}= & \alpha_{0}+\alpha_{1} \ln \mathrm{PL}_{i t}+\alpha_{2} \ln \mathrm{PK}_{i t}+\alpha_{3} \ln \mathrm{PF}_{i t}{ }_{2} \\
& +\beta_{1} \ln \text { Rissass }_{i t}+\beta_{2} \ln \operatorname{Asset}_{i t}+\mu_{i}+v_{i t}
\end{aligned}
$$

$H$ value is expressed as $h=\alpha_{1}+\alpha_{2}+\alpha_{3}$.

The sample period of this study is from 2008 to 2017, including data of 15 banks. The selection of this sample is very representative and can reflect the overall development situation of China's commercial Banks. The specific meaning of variable is shown in Table 2.

\section{Empirical Analysis}

The main tests used in this paper are equilibrium test and overall competition test. However, before we officially start analyzing this model, it is needed to know whether the model matches the data or not. It can be clearly seen from Table 3 that the $P$ value of both Cross-section Chi-square test and the Period Chi-square test is equal to 0 , and it means no matter the cross-section fixed effects or the period fixed effects are exactly equal 0 . The panel data models with both cross-section and period effects are matching the data. Moreover, from Table 4, it is clear that the two DW values are 1.320 and 1.179 respectively, which indicates that there is a positive autocorrelation in our sequence.

\subsection{Competition Test}

Because of the cost differential in China's banking industry, the fixed effect model is adopted in this paper. It can be seen from Table 5 that the $\mathrm{R}^{2}$ value is 0.565 and the test statistic in the Hausman test was 14.770, which passed the F-statistic test at the significance level of $5 \%$ and the $10 \%$ level, so the competition model is reasonable. Because of $\mathrm{R}^{2}$ of this regression equation is 0.565 and the adjusted $R^{2}$ is 0.5202 , fitting effect is relatively satisfactory. Furthermore, the value of F-statistic is 9.020, indicating that there is a significant linear relationship between variables. In this paper, $H$ value is tested by the Wald test. Under the hypothesis of $H=1$ and $H=0$, the amount of statistics is 144.105 and 2.538 respectively, the corresponding $p$-value is 0 and 0.111 . Therefore, both of the ${ }^{2} \mathrm{REV}$ represents the operating return on total assets, which is equal to the ratio of total revenue to total assets. PL is the cost per capita ratio, expressed by the ratio of personnel expenses to employees. PK is the rate of cost on the asset, expressed by the ratio of operating costs to total assets. $\mathrm{PF}$ is the rate of cost of capital, expressed by the ratio of interest expense to total deposits. Riskass means a measure of the risk level of Banks' operations, which is equal to the ratio of total loans to total assets. Assets refer to the size of a bank, scholars usually uses total assets to indicate whether a bank has economies of scale. $\mu_{i}$ is a specific fixed effect of a bank, $\mathrm{v}$ is an error term, $i$ means the $i$ th bank, and $t$ is the time. 
Table 2. Specific meaning of variable in market equilibrium test model.

\begin{tabular}{cccccc}
\hline Variables & Definition & Mean & S.D & Minimum & Maximum \\
\hline REV $_{i t}$ & total revenue/total assets & 0.028095 & 0.003875 & 0.020254 & 0.038356 \\
$\mathrm{PL}_{i t}$ & personnel expenses/employees & 298020.3 & 84624.8 & 108583 & 484803.6 \\
$\mathrm{PK}_{i t}$ & operating costs/total assets & 0.00027915 & 0.00049043 & 0.000003 & 0.0023417 \\
$\mathrm{PF}_{i t}$ & interest expenditure/total deposits & 0.029956 & 0.010417 & 0.012996 & 0.054808 \\
Rissass $_{i t}$ & total loans/total assets & 0.491408 & 0.069528 & 0.304781 & 0.624423 \\
Asset $_{i t}$ & the log of total assets & 28.74032 & 1.246299 & 25.26343 & 30.89246 \\
ROA $_{i t}$ & net profit/ total assets & 0.1849356 & 0.0395072 & 0.0432 & 0.3671 \\
\hline
\end{tabular}

Table 3. Redundant fixed effects test.

\begin{tabular}{|c|c|c|c|c|c|c|c|c|c|}
\hline Effects Test & & Statistic & d.f. & Prob. & Effects Test & & Statistic & d.f. & Prob. \\
\hline Cross-section F & & 8.886 & $-15,139.000$ & 0.000 & Cross-section F & & 4.804 & $-15,139.000$ & 0.000 \\
\hline Test Summary & & Chi-Sq. Statistic & Chi-Sq. d.f. & Prob. & Test Summary & & Chi-Sq. Statistic & Chi-Sq. d.f. & Prob. \\
\hline $\begin{array}{l}\text { Cross-section } \\
\text { random }\end{array}$ & & 14.770 & 5.000 & 0.011 & $\begin{array}{l}\text { Cross-section } \\
\text { random }\end{array}$ & & 27.952 & 5.000 & 0.000 \\
\hline Test Statistic & Value & df & Probability & & Test Statistic & Value & df & Probability & \\
\hline t-statistic & -12.004 & 139.000 & 0.000 & & t-statistic & -6.464 & 139.000 & 0.000 & \\
\hline F-statistic & 144.105 & $(1,139)$ & 0.000 & & F-statistic & 41.777 & $(1,139)$ & 0.000 & \\
\hline Test Statistic & Value & df & Probability & & Test Statistic & Value & df & Probability & \\
\hline t-statistic & 1.593 & 139.000 & 0.113 & & t-statistic & 0.297 & 139.000 & 0.767 & \\
\hline F-statistic & 2.538 & $(1,139)$ & 0.113 & & F-statistic & 0.088 & $(1,139)$ & 0.767 & \\
\hline Chi-square & 2.538 & 1.000 & 0.111 & & Chi-square & 0.088 & 1.000 & 0.766 & \\
\hline
\end{tabular}

Table 4. Panel option.

\begin{tabular}{|c|c|c|c|c|c|c|c|c|c|}
\hline Variable & Coefficient & Std. Error & $\mathrm{t}$-Statistic & Prob. & Variable & Coefficient & Std. Error & $\mathrm{t}$-Statistic & Prob. \\
\hline LNPL & -0.145 & 0.072 & -2.007 & 0.047 & LNPL & 0.172 & 0.146 & 1.182 & 0.239 \\
\hline LNPF & 0.262 & 0.039 & 6.702 & 0.000 & LNPF & 0.135 & 0.079 & 1.712 & 0.089 \\
\hline LNRISK & 0.246 & 0.133 & 1.847 & 0.067 & LNRISK & -0.975 & 0.268 & -3.644 & 0.000 \\
\hline LNASSET & -0.012 & 0.032 & -0.380 & 0.705 & LNASSET & -0.241 & 0.065 & -3.720 & 0.000 \\
\hline $\mathrm{C}$ & -0.287 & 0.773 & -0.371 & 0.711 & $\mathrm{C}$ & 6.529 & 1.555 & 4.199 & 0.000 \\
\hline $\begin{array}{l}\text { Cross-section fixed } \\
\text { (dummy variables) }\end{array}$ & & & & & $\begin{array}{l}\text { Cross-section fixed } \\
\text { (dummy variables) }\end{array}$ & & & & \\
\hline R-squared & 0.565 & $\begin{array}{c}\text { Mean } \\
\text { dependent var }\end{array}$ & & -3.582 & R-squared & 0.371 & $\begin{array}{c}\text { Mean } \\
\text { dependent var }\end{array}$ & & 2.893 \\
\hline
\end{tabular}




\section{Continued}

\begin{tabular}{|c|c|c|c|c|c|c|c|}
\hline Adjusted R-squared & 0.502 & $\begin{array}{c}\text { S.D. } \\
\text { dependent var }\end{array}$ & 0.138 & Adjusted R-squared & 0.281 & $\begin{array}{c}\text { S.D. } \\
\text { dependent var }\end{array}$ & 0.231 \\
\hline S.E. of regression & 0.097 & $\begin{array}{c}\text { Akaike } \\
\text { info criterion }\end{array}$ & -1.700 & S.E. of regression & 0.196 & $\begin{array}{c}\text { Akaike } \\
\text { info criterion }\end{array}$ & -0.303 \\
\hline Sum squared reside & 1.316 & $\begin{array}{l}\text { Schwarz } \\
\text { criterion }\end{array}$ & -1.296 & Sum squared resid & 5.324 & $\begin{array}{l}\text { Schwarz } \\
\text { criterion }\end{array}$ & 0.101 \\
\hline Log likelihood & 157.001 & $\begin{array}{l}\text { Hannan-Quinn } \\
\text { criter. }\end{array}$ & -1.536 & Log likelihood & 45.206 & $\begin{array}{l}\text { Hannan-Quinn } \\
\text { criter. }\end{array}$ & -0.139 \\
\hline F-statistic & 9.020 & $\begin{array}{c}\text { Durbin-Watson } \\
\text { stat }\end{array}$ & 1.320 & F-statistic & 4.106 & $\begin{array}{c}\text { Durbin-Watson } \\
\text { stat }\end{array}$ & 1.179 \\
\hline $\operatorname{Prob}(F-$ statistic) & 0.000 & & & Prob(F-statistic) & 0.000 & & \\
\hline
\end{tabular}

Table 5. The regression result of competition degree of Chinese banking industry.

\begin{tabular}{|c|c|c|c|c|}
\hline Variable & Coefficient & Std. Error & t-Statistic & Prob. \\
\hline LNPL & $-0.145^{\star * *}$ & 0.072 & -2.007 & 0.047 \\
\hline LNPK & $0.001^{\star * *}$ & 0.008 & 0.075 & 0.941 \\
\hline LNPF & $0.262^{\star * *}$ & 0.039 & 6.702 & 0.000 \\
\hline LNRISK & $0.246^{\star * *}$ & 0.133 & 1.847 & 0.067 \\
\hline LNASSET & $-0.012^{\star \star *}$ & 0.032 & -0.380 & 0.705 \\
\hline R-squared & \multicolumn{4}{|c|}{0.565} \\
\hline Adj.R-squared & \multicolumn{4}{|c|}{0.502} \\
\hline F-statistic & \multicolumn{4}{|c|}{9.020} \\
\hline F-test & 8.886 & & & 0.000 \\
\hline Hausman-Test & 14.770 & & & 0.011 \\
\hline$H_{0}: H=1$ & 144.105 & & & 0.000 \\
\hline$H_{1}: H=0$ & 2.538 & & & 0.111 \\
\hline
\end{tabular}

${ }^{* * *},{ }^{* *}$ and ${ }^{*}$ represent significance levels of $1 \%, 5 \%$ and $10 \%$ respectively, and Wald test uses $\chi^{2}$ statistics.

original hypotheses are rejected. The hypothesis of $0<H<1$ should be accepted, which means the Chinese banking market is a monopolistic and competitive market.

\subsection{Equilibrium Test}

In this paper, $\mathrm{ROA}$ is used as the explanatory variable of equilibrium test, and $H$ statistic is used to measure the equilibrium of China's banking market. It can be found from Table 6 that the $\mathrm{R}^{2}$ in this regression equation is 0.371 , and the adjusted $R^{2}$ is 0.281 . The fitting effect is relatively satisfactory. Moreover, the F statistic is 4.106 , which passed the significance test at $5 \%$ level, indicating that the equilibrium test model of the bank was set up reasonably. In this model, $H$ statistic is also assumed to be: $h=\alpha_{1}+\alpha_{2}+\alpha_{3}$. Therefore, when $H=0$, the $p$-value is 0.766 , so the original hypothesis that $H=0$ is accepted at the significant level of 
Table 6. The regression result of equilibrium test of Chinese banking industry.

\begin{tabular}{|c|c|c|c|c|}
\hline Variable & Coefficient & Std. Error & t-Statistic & Prob. \\
\hline LNPL & 0.172 & 0.146 & 1.182 & 0.239 \\
\hline LNPK & 0.006 & 0.016 & 0.411 & 0.682 \\
\hline LNPF & $0.135^{*}$ & 0.079 & 1.712 & 0.089 \\
\hline LNRISK & $-0.975^{*}$ & 0.268 & -3.644 & 0.000 \\
\hline LNASSET & $-0.241^{\star *}$ & 0.065 & -3.720 & 0.000 \\
\hline R-squared & \multicolumn{4}{|c|}{0.371} \\
\hline Adj.R-squared & \multicolumn{4}{|c|}{0.281} \\
\hline F-statistic & \multicolumn{4}{|c|}{4.106} \\
\hline F-test & 4.804 & & & 0.000 \\
\hline Hausman-Test & 27.952 & & & 0.000 \\
\hline$H_{0}: H=1$ & 41.777 & & & 0.000 \\
\hline$H_{1}: H=0$ & 0.088 & & & 0.766 \\
\hline
\end{tabular}

5\%, which means the Chinese banking market meets the equilibrium conditions from 2008 to 2017.

In conclusion, this paper uses PR model to test the competition degree of Chinese banking industry and finds that Chinese commercial Banks stay in a long-term equilibrium and monopolistic competition state.

\section{Conclusion}

Through the analysis of Panzar-Rosse model, this paper studies the market competition of Chinese Banks from 2008 to 2017 and establishes the relevant competition detection model and the equilibrium detection model. It is found that the market structure of China's commercial Banks is transitioning from oligopoly market to monopolistic competition market. Furthermore, the Chinese banking industry is always in a long-term equilibrium state in this process. Although competition among Banks is increasing and the monopoly of state-owned Banks is decreasing, the market control ability of state-owned Banks is still very strong compared with joint-stock Banks. Therefore, lowering the market access threshold and increasing the market share of joint-stock Banks will help improve the market competition environment.

However, there are some shortcomings in this paper. It is clear that the current banking competition is not only between traditional businesses but also gradually shifting to the intermediate businesses. Owing to lack of the information and data that related to the intermediary business, especially for small and medium-sized joint-stock Banks, this paper can only analyze the competition status of Banks by comparing the competition degree of total revenue and the changes of relevant investment coefficient. Although there are some defects, the theoretical structure and results of this paper have already been very clear and 
complete. This essay can basically show the current competition and balance of China's banking market.

\section{Conflicts of Interest}

The authors declare no conflicts of interest regarding the publication of this paper.

\section{References}

Bikker, J. A., \& Haaf, K. (2002). Competition, Concentration and Their Relationship: An Empirical Analysis of the Banking Industry. Journal of Banking \& Finance, 26, 2191-2214. https://doi.org/10.1016/S0378-4266(02)00205-4

Gunji, H., \& Yuan, Y. (2017). The Panzar-Rosse Statistic Revisited. Theoretical Economics Letters, 7, 30-34. https://doi.org/10.4236/tel.2017.71004

Hempell, H. S. (2002). Testing for Competition among German Banks. https://doi.org/10.2139/ssrn.304343

Molyneux, P., Lloyd-Williams, D. M., \& Thornton, J. (1994). Competitive Conditions in European Banking. Journal of Banking \& Finance, 18, 445-459. https://doi.org/10.1016/0378-4266(94)90003-5

Panzar, J. C., \& Rosse, J. N. (1987). Testing for “Monopoly" Equilibrium. The Journal of Industrial Economics, 35, 443-456. https://doi.org/10.2307/2098582

Shaffer, S. (1982). Competition, Conduct and Demand Elasticity. Economics Letters, 10, 167-171. https://doi.org/10.1016/0165-1765(82)90132-X 